This first volume contains thirteen date lists and one paper (Lamont VI) devoted entirely to measurements on samples of known age. This aspect of radiocarbon dating research has assumed considerable importance in recent years, for it yields information on the past and present distribution of radiocarbon in the carbon exchange reservoir, and this is of particular inportance when one is concerned with the attainment of the highest possible accuracy in radiocarbon dates.

In addition to these contributions from dating laboratories, there is a very useful bibliography by Frederick Johnson, which gives references to all previous date lists, and a list of all laboratories known to be or to have been concerned with radiocarbon dating measurements. Thirty-six laboratories are listed, and it might be wondered why only about a third of them have contributed to this new publication. However, if one takes into account the fact that some have now ceased to be active in this field and that others have only recently begun operating, the response to this new project is not unsatisfactory. The editors have attempted to secure a high standard of presentation by requiring contributors to adhere as closely as possible to a set style and to include much informative detail regarding each sample in addition to its laboratory number and radiocarbon age. In general, the various authors have responded well to these requirements, and the standard achieved in this first volume promises well for the future. The Supplement is to be published annually, in May, at Sterling Tower, Yale University, New Haven, Connecticut; subscription rate 4.50 dollars a year; Vol. 1 will be sold for 2.50 dollars until January 1, 1960.

\section{Inland Waterways in Britain}

AN interesting feature of the sixty-fourth annual report of the National Trust, for 1958-59 (London : National Trust), which records a welcome increase in free legacies and donations, is the reference to negotiations with the British Transport Commission for the acquisition of the southern section of the Stratford-upon-Avon canal and the southern section of the Staffordshire and Worcestershire canal. Since then it has been announced that, under an agreement to be approved by Parliament, the National Trust will lease the first of these canals for a trial period of five years, when it can be transferred outright or returned to the British Transport Commission. For the five years the National Trust will receive $£ 1,500$ a year from the Commission and the Trust will be able to provide in the towpath a thirteen. mile traffic-free walk through a remote and interesting countryside. Unless transferred to the Trust, this canal will be abandoned (at an estimated cost of $£ 120,000$ ) and the pleasures of fishing and boating on it would also be lost to the community. The second canal is of extreme beauty and importance and is James Brindley's earliest canal with locks. The Trust already owns property on this canal at Kinver and Wightwick. These transfers, which are foreshadowed in the Bowes Report on Inland Waterways, represent a new departure, both for the Trust and the Commission, and the legal and financial arrangements are not expected to be completed simply or rapidly. The report pays tribute to the help given by voluntary workers in scrub clearance, but, although the membership over the past fourteen years has risen from 10,300 to 80,668 , many more members are needed if membership is fairly to refiect the wide responsibilities of the Trust and to support the extension of its work.

\section{Newspaper Trusts}

IN Broadsheet No. 435, "The Work of Newspaper Trusts", Political and Economic Planning provides a concise account of the various newspaper trusts, their purpose and character and organization, with a view of assisting the assessment of their performance (Planning, 25 ; 24 August 1959. London : Political and Economic Planning, 1959. 3s. 6d.). The fullest accounts given are of the Scott Trust, holding all ordinary shares in the Manchester Guardian and Evening News, Ltd., and the Observer Trust, but there are also notes on the provisions in the articles of association of The Times, The Economist and The Spectator. The Broadsheet points out that the organization of such a trust must be devised for the end to be served, and that many different methods may be adopted. Too precise a definition of a trust's aims or ideals could be harmful if circumstances changed. To form opinion and build good traditions and to appoint men of good sense to positions of responsibility are all that can wisely or legitimately be done to control the future. A newspaper trust is a novel but long-dated attempt to keep a newspaper in conformity with an existing ideal over future generations and it is still too early to judge how far these experiments have contributed to maintain the health and standards of the Press. It remains to be seen whether trusts can be more successful than other forms of proprietorship and control in preserving and developing the independence and character of a newspaper and simultaneously in achieving sufficient success to stay in business, if not to lead the field.

\section{British Museum (Natural History)}

Among the more important and interesting items reported to the Trustees of the British Museum at their meeting at the British Museum (Natural History) on November 28 was that Dr. G. H. Francis and Dr. A. J. Charig had returned from their expedition to South Peru. This expedition, the second from the Museum to this area, had for its objective the further study, collection and mapping of the rocks of the Province of Carabaya, in the Department of Puno, together with fossil collecting from new sites in Carabaya. The mapping, field geology and detailed study of igneous rocks were in the charge of Dr. Francis, of the Department of Mineralogy, continuing the work begun on the previous expedition which he led in 1954. The fossil and anthropological collections were made by Dr. Charig, of the Department of Palæontology. They were assisted by Messrs. S. G. $\mathrm{McH}$. Clark and B. L. Holt, University of Cambridge, and by Sr. H. Salazar Dias, University of Arequipa. The expedition was in the field from June I until August 1, 1959. More than four hundred specimens of rocks and minerals were collected in the present field season. The survey of the area was continued, and a substantial number of fossils were assembled. In addition, the expedition brought home some anthropological material from Inca burials. Mrs. Rees Thomas and Lady Barlow have lent to the Museum a letter from Charles Darwin, dated July 5, 1844, asking his wife to arrange for the publication of his Essay on Transmutation of Species in the event of his death. The latter has been placed on exhibition in the case of Darwin relics, now on view in the Central Hall of the Museum. 